\title{
PAPER
}

\section{Aetiological diagnosis of brain abscesses and spinal infections: application of broad range bacterial polymerase chain reaction analysis}

\author{
L Kupila, K Rantakokko-Jalava, J Jalava, S Nikkari, R Peltonen, O Meurman, \\ R J Marttila, E Kotilainen, P Kotilainen
}

See end of article for authors' affiliations

Correspondence to:

Dr Laura Kupila,

Department of Neurology,

Turku University Central

Hospital, Kiinamyllynkatu

4-8, 20520 Turku, Finland;

laura.kupila@tyks.fi

Received 9 July 2002

In revised form

28 November 2002

Accepted

28 January 2003

\begin{abstract}
Objective: To evaluate the usefulness of the broad range bacterial rDNA polymerase chain reaction (PCR) method combined with DNA sequencing in the aetiological diagnosis of intracranial or spinal infections in neurosurgical patients.

Methods: In addition to conventional methods, the broad range bacterial PCR approach was applied to examine pus or tissue specimens from cerebral or spinal lesions in patients treated in a neurosurgical unit for a clinical or neuroradiological suspicion of bacterial brain abscess or spondylitis.

Results: Among the 44 patients with intracranial or spinal lesions, the final diagnosis suggested bacterial disease in 25 patients, among whom the aetiological agent was identified in 17. A causative bacterial species was identified only by the rDNA PCR method in six cases, by both the PCR methodology and bacterial culture in six cases, and by bacterial culture alone in five. All samples in which a bacterial aetiology was identified only by the PCR approach were taken during antimicrobial treatment, and in three patients the method yielded the diagnosis even after $\geqslant 12$ days of parenteral treatment. One case also identified by the PCR approach alone involved a brain abscess caused by Mycoplasma hominis, which is not readily cultured by routine methods.

Conclusions: In patients with brain abscesses and spinal infections, the broad range bacterial rDNA PCR approach may be the only method to provide an aetiological diagnosis when the patient is receiving antimicrobial treatment, or when the causative agent is fastidious.
\end{abstract}

n recent years, molecular methods have increasingly been used to detect microbes in various clinical samples, including those from patients with central nervous system infections. In patients with suspected bacterial meningitis, specific polymerase chain reaction (PCR) techniques have been used for the identification of Neisseria meningitidis, ${ }^{1-3}$ Streptococcus pneumoniae, ${ }^{5}$ and Listeria monocytogenes ${ }^{6}$ or for the simultaneous detection of Neisseria meningitidis, Haemophilus influenzae, and streptococci in cerebrospinal fluid (CSF) samples. ${ }^{78}$ The aetiology of community acquired bacterial meningitis has also been assessed using PCR with broad range bacterial primers combined with DNA sequencing in CSF. ${ }^{90}$ These PCR primers are targeted at the most conserved bacterial rDNA gene sequences, rendering possible the detection of practically any bacterial species in the sample. The bacterial species can then be identified by comparing the DNA sequence of the amplification product with previously published bacterial sequence types. ${ }^{11}$

PCR techniques have also been applied in the aetiological diagnostics of brain abscesses. Reports on the use of specific PCR assays in cerebral specimens from patients with brain abscesses have focused mainly on toxoplasma infections, ${ }^{12}{ }^{13}$ but there are also papers describing the use of specific PCR assays to identify, for example, Entamoeba histolytica in pus from brain abscess ${ }^{14}$ or Mycobacterium tuberculosis in tuberculous brain lesions. ${ }^{15}$ One case report has described identification of Fusobacterium species in a brain abscess, and another, Streptococcus pneumoniae in a subdural empyema, by the broad range bacterial PCR approach alone. ${ }^{16}{ }^{17}$

We have previously used broad range bacterial rDNA PCR to analyse 536 clinical samples of various tissues from patients admitted to hospital during the years 1994 to 1997. That work also included samples obtained during neurosurgery, but the patients involved were not further described nor the results specifically discussed. 'Subsequently, the PCR method has been applied in our hospital to analyse intracranial and spinal specimens from neurosurgical patients, when the procedure was considered clinically indicated by the attending clinicians. We describe here our experience of the value of this technique in diagnosing suspected bacterial intracranial or spinal infection at the neurosurgical department of a university hospital in Finland.

\section{METHODS}

From the beginning of 1995 to the end of 2000, 44 pus or tissue samples from neurosurgical patients treated at the department of neurosurgery, Turku University Hospital, Turku, Finland, were analysed by the PCR method, in addition to conventional microbiological methods. These patients were suspected of having bacterial infection in brain tissue or spinal canal.

\section{Patients and samples}

The study collection included 24 intracranial and 20 spinal samples. The intracranial pus or tissue samples were from patients operated on for a clinical or neuroradiological suspicion of brain abscess or subdural empyema, or when the intraoperative nature of the lesion remained macroscopically undefined. Eleven samples were obtained by trepanation and puncture, and 13 by stereotactic or open biopsy (table 1). The spinal samples were from patients who underwent neurosurgery for suspected spondylitis or spinal epidural abscess. The samples included five pus and 15 tissue specimens, of which 18 were obtained by biopsy during laminectomy, one tissue specimen was obtained by stereotactic biopsy, and one pus specimen was obtained by puncture (table 2 ).

Data were collected on the final clinical diagnoses as well as on the administration of antimicrobials and the timing of the 
Table 1 Results of analyses of specimens from 24 patients with suspected intracranial infection: broad range bacterial PCR, DNA sequencing, bacterial culture, data on operative technique and preoperative antimicrobial treatment, and final diagnosis

\begin{tabular}{|c|c|c|c|c|c|c|c|c|c|c|}
\hline No & $\begin{array}{l}\text { Initial } \\
\text { diagnosis }\end{array}$ & $\begin{array}{l}\text { Operative } \\
\text { technique }\end{array}$ & $\begin{array}{l}\text { Intracranial } \\
\text { specimen }\end{array}$ & $\begin{array}{l}\text { Bacterial culture } \\
\text { result }\end{array}$ & PCR & Sequencing result & $\begin{array}{l}\text { Homology } \\
(\%)^{a}\end{array}$ & $\begin{array}{l}\text { Sequence } \\
\text { length } \\
(\text { nt })^{a}\end{array}$ & $\begin{array}{l}\text { Preoperative } \\
\text { antibiotics }^{b}\end{array}$ & Final diagnosis \\
\hline 1 & Brain abscess & Puncture & Pus & Str equinus & + & Str intermedius & 98.1 & 423 & $\begin{array}{l}\text { Yes (14 } \\
\text { hours) }\end{array}$ & Brain abscess \\
\hline 2 & $\begin{array}{l}\text { Brain abscess } \\
\text { or metastasis }\end{array}$ & $\begin{array}{l}\text { Open } \\
\text { biopsy }\end{array}$ & Pus & $\begin{array}{l}\text { Streptococcus (sp. } \\
\text { viridans group) }\end{array}$ & + & $\begin{array}{l}\text { Streptococcus (sp } \\
\text { milleri group) }\end{array}$ & 99.6 & 458 & No & Brain abscess \\
\hline 3 & Brain abscess & Puncture & Pus & $\begin{array}{l}\text { Str intermedius/ } \\
\text { anginosus }\end{array}$ & + & $\begin{array}{l}\text { Str intermedius/ } \\
\text { anginosus }\end{array}$ & 99.4 & 349 & Yes (5 days) & Brain abscess \\
\hline 4 & Glioblastoma & $\begin{array}{l}\text { Open } \\
\text { biopsy }\end{array}$ & Pus & $\begin{array}{l}\text { Peptostreptococcus } \\
\text { sp }\end{array}$ & + & $\begin{array}{l}\text { Peptostreptococcus } \\
\text { sp }\end{array}$ & 95.7 & 243 & $\begin{array}{l}\text { Yes (12 } \\
\text { hours) }\end{array}$ & Brain abscess \\
\hline 5 & $\begin{array}{l}\text { Postoperative } \\
\text { brain abscess }\end{array}$ & Puncture & Pus & $\begin{array}{l}\text { Propionibacterium } \\
\text { acnes }\end{array}$ & + & $\begin{array}{l}\text { Propionibacterium } \\
\text { acnes }\end{array}$ & 99.7 & 299 & No & $\begin{array}{l}\text { Postoperative } \\
\text { brain abscess }\end{array}$ \\
\hline 6 & Brain abscess & Puncture & Pus & $\begin{array}{l}\text { Bacteroides } \\
\text { gracilis, } \\
\text { Peptostreptococcus, } \\
\text { Str intermedius }\end{array}$ & + & Several species ${ }^{c}$ & & & No & Brain abscess \\
\hline 7 & $\begin{array}{l}\text { Postoperative } \\
\text { brain abscess }\end{array}$ & Puncture & Pus & $-^{d}$ & + & Staph aureus & 98.6 & 441 & Yes (5 days) & $\begin{array}{l}\text { Postoperative } \\
\text { brain abscess }\end{array}$ \\
\hline 8 & $\begin{array}{l}\text { Post-traumatic } \\
\text { brain abscess }\end{array}$ & Puncture & Pus & - & + & $\begin{array}{l}\text { Mycoplasma } \\
\text { hominis }\end{array}$ & 99.8 & 499 & Yes (10 days) & $\begin{array}{l}\text { Post-traumatic } \\
\text { brain abscess }\end{array}$ \\
\hline 9 & $\begin{array}{l}\text { Postoperative } \\
\text { subdural } \\
\text { empyema }\end{array}$ & Puncture & Pus & - & + & Failure ${ }^{e}$ & & & No & $\begin{array}{l}\text { Postoperative } \\
\text { subdural } \\
\text { empyema }\end{array}$ \\
\hline 10 & $\begin{array}{l}\text { Postoperative } \\
\text { subdural } \\
\text { empyema }\end{array}$ & $\begin{array}{l}\text { Open } \\
\text { biopsy }\end{array}$ & Pus & Staph aureus & - & & & & Yes (3 days) & $\begin{array}{l}\text { Postoperative } \\
\text { subdural } \\
\text { empyema }\end{array}$ \\
\hline 11 & Brain abscess & Puncture & Pus & Fusobacterium sp & - & & & & No & Brain abscess \\
\hline 12 & Brain abscess & $\begin{array}{l}\text { Stereotactic } \\
\text { biopsy }\end{array}$ & Pus & - & - & & & & Yes (60 days) & $\begin{array}{l}\text { Aspergillus sp, } \\
\text { brain abscess }\end{array}$ \\
\hline 13 & Brain abscess & Puncture & Pus & - & - & & & & $\begin{array}{l}\text { Yes }^{f}(111 \\
\text { days) }\end{array}$ & Brain abscess \\
\hline 14 & Brain abscess & Puncture & Pus & - & - & & & & Yes $^{f}$ (7 days) & Brain abscess \\
\hline 15 & $\begin{array}{l}\text { Brain tumour } \\
\text { or infection }\end{array}$ & $\begin{array}{l}\text { Stereotactic } \\
\text { biopsy }\end{array}$ & Brain tissue & - & - & & & & No & Demyelination \\
\hline 16 & CNS infection & $\begin{array}{l}\text { Stereotactic } \\
\text { biopsy }\end{array}$ & Brain tissue & Not done & - & & & & No & $\begin{array}{l}\text { Unspecific } \\
\text { gliosis }\end{array}$ \\
\hline 17 & CNS infection & $\begin{array}{l}\text { Stereotactic } \\
\text { biopsy }\end{array}$ & Cysta liquid & - & - & & & & Yes (13 days) & $\begin{array}{l}\text { Parvocellular } \\
\text { carcinoma }\end{array}$ \\
\hline 18 & $\begin{array}{l}\text { Unclear } \\
\text { progressive } \\
\text { brain disease }\end{array}$ & $\begin{array}{l}\text { Stereotactic } \\
\text { biopsy }\end{array}$ & Brain tissue & - & - & & & & $\begin{array}{l}\text { Yes (one } \\
\text { dose) }\end{array}$ & Glioblastoma \\
\hline 19 & $\begin{array}{l}\text { Unclear brain } \\
\text { lesion }\end{array}$ & Puncture & Brain tissue & - & - & & & & Yes (5 days) & Glioblastoma \\
\hline 20 & $\begin{array}{l}\text { Brain tumour } \\
\text { or abscess }\end{array}$ & $\begin{array}{l}\text { Open } \\
\text { biopsy }\end{array}$ & Brain tissue & Not done & - & & & & $\begin{array}{l}\text { Yes (one } \\
\text { dose) }\end{array}$ & Glioblastoma \\
\hline 21 & $\begin{array}{l}\text { Brain tumour } \\
\text { or abscess }\end{array}$ & $\begin{array}{l}\text { Stereotactic } \\
\text { biopsy }\end{array}$ & Brain tissue & $\begin{array}{l}\text { Propionibacterium } \\
\text { sp }\end{array}$ & - & & & & No & Astrocytoma \\
\hline 22 & $\begin{array}{l}\text { Brain tumour } \\
\text { or abscess }\end{array}$ & $\begin{array}{l}\text { Stereotactic } \\
\text { biopsy }\end{array}$ & Brain tissue & - & - & & & & No & Lymphoma \\
\hline 23 & Brain abscess & $\begin{array}{l}\text { Stereotactic } \\
\text { biopsy }\end{array}$ & Brain tissue & - & - & & & & Yes (4 days) & Lymphoma \\
\hline 24 & Tumour & $\begin{array}{l}\text { Open } \\
\text { biopsy }\end{array}$ & $\begin{array}{l}\text { Mucous } \\
\text { liquid }\end{array}$ & - & - & & & & $\begin{array}{l}\text { Yes (one } \\
\text { dose) }\end{array}$ & Mucocele \\
\hline
\end{tabular}

'The per cent homology and the length of the overlapping sequence for the best match.

${ }^{b}$ An effective antimicrobial treatment against the recognised microbe in the specimen; duration of preoperative antibiotic treatment is given in parentheses. 'The sample was interpreted to contain several species if the electropherogram showed strong signals but multiple overlapping peaks in some locations. Negative result.

e Sequencing failure was assumed if the sequencing signals reported by the instrument were weak.

The patient received ceftriaxone and metronidazole.

CNS, central nervous system; nt, nucleotides; PCR, polymerase chain reaction.

microbiological specimens with respect to antimicrobial treatment. All positive PCR or culture results were reassessed to determine the clinical importance of the findings.

\section{DNA purification}

DNA was extracted from the fresh tissue samples after proteinase $\mathrm{K}(0.1 \mathrm{mg} / \mathrm{ml})$ digestion $\left(56^{\circ} \mathrm{C}\right.$, two to 17 hours $)$ with two phenol-chloroform-isoamyl alcohol extractions followed by one ether wash, as described earlier. ${ }^{18}$ Pus samples were concentrated by centrifugation ${ }^{19}$ and DNA extraction was done as described above.

\section{PCR}

The primers, reagents, and conditions used in the $23 \mathrm{~S}$ and $16 \mathrm{~S}$ rDNA PCR have been described previously. ${ }^{10}$ All samples were initially screened for the presence of bacterial DNA by amplification of the 23S rRNA genes with oligonucleotide primers MS 37 and MS $38 .{ }^{10}$ On the basis of sequence analysis of the $23 \mathrm{~S}$ rDNA, these primers cover several bacterial subdivisions, as described previously. ${ }^{10}$

The bacterial DNA present in a $23 \mathrm{~S}$ rDNA PCR positive specimen was identified by sequencing the $23 \mathrm{~S}$ or $16 \mathrm{~S}$ rDNA, or both. Amplification of the 23S rDNA was used in the initial screening of the samples because of its higher sensitivity compared with that of the previously described 16S rDNA PCR method. The 16S rDNA PCR product was preferred for sequencing because of the more abundant sequence data presently available.

Special care was taken to avoid contamination of samples with amplicons. ${ }^{20}$ Strict measures were employed to separate 
Table 2 Results of analyses of specimens from 20 patients with suspected spondylitis or epidural abscess: broad range bacterial PCR, DNA sequencing, bacterial culture, data on operative technique, preoperative antimicrobial treatment, and blood cultures, and final diagnosis

\begin{tabular}{|c|c|c|c|c|c|c|c|c|c|c|c|}
\hline No & $\begin{array}{l}\text { Initial } \\
\text { diagnosis }\end{array}$ & $\begin{array}{l}\text { Operative } \\
\text { technique }\end{array}$ & $\begin{array}{l}\text { Spinal } \\
\text { specimen }\end{array}$ & $\begin{array}{l}\text { Bacterial } \\
\text { culture result }\end{array}$ & PCR & $\begin{array}{l}\text { Sequencing } \\
\text { result }\end{array}$ & $\begin{array}{l}\text { Homology } \\
(\%)^{\mathrm{a}}\end{array}$ & $\begin{array}{l}\text { Sequence } \\
\text { ylength } \\
\text { (nt) }\end{array}$ & $\begin{array}{l}\text { Preoperative } \\
\text { antibiotics }^{\mathrm{b}}\end{array}$ & $\begin{array}{l}\text { Blood culture } \\
\text { result }^{c}\end{array}$ & Final diagnosis \\
\hline 1 & Spondylitis & $\begin{array}{l}\text { Open } \\
\text { biopsy }\end{array}$ & Pus & Staph aureus & + & $\begin{array}{l}\text { Staphylococcus } \\
\text { sp, probably } \\
\text { several }_{\text {species }^{d}}\end{array}$ & 86.3 & 164 & Yes (8 days) & $\begin{array}{l}\text { Staph aureus } \\
\text { (-8 days) }\end{array}$ & $\begin{array}{l}\text { Spondylitis and } \\
\text { epidural } \\
\text { abscess }\end{array}$ \\
\hline 2 & $\begin{array}{l}\text { Epidural } \\
\text { abscess }\end{array}$ & $\begin{array}{l}\text { Open } \\
\text { biopsy }\end{array}$ & Pus & $-{ }^{e}$ & + & $\begin{array}{l}\text { Staphylococcus } \\
\text { sp }\end{array}$ & 94.7 & 216 & $\begin{array}{l}\text { Yes (15 } \\
\text { days) }\end{array}$ & $\begin{array}{l}\text { Staph aureus } \\
\text { (-15 days) }\end{array}$ & $\begin{array}{l}\text { Epidural } \\
\text { abscess }\end{array}$ \\
\hline 3 & Spondylitis & $\begin{array}{l}\text { Open } \\
\text { biopsy }\end{array}$ & $\begin{array}{l}\text { Bone and } \\
\text { disc }\end{array}$ & - & + & Staph aureus & 98.6 & 441 & $\begin{array}{l}\text { Yes (12 } \\
\text { days) }\end{array}$ & $\begin{array}{l}\text { Staph aureus } \\
\text { (-14 days) }\end{array}$ & Spondylitis \\
\hline 4 & $\begin{array}{l}\text { Postoperative } \\
\text { spondylodiscitis }\end{array}$ & $\begin{array}{l}\text { Open } \\
\text { biopsy }\end{array}$ & Pus & - & + & Str intermedius & 98.1 & 423 & $\begin{array}{l}\text { Yes (13 } \\
\text { days) }\end{array}$ & Not done & $\begin{array}{l}\text { Postoperative } \\
\text { spondylodiscitis }\end{array}$ \\
\hline 5 & $\begin{array}{l}\text { Vertebral } \\
\text { tumour }\end{array}$ & $\begin{array}{l}\text { Open } \\
\text { biopsy }\end{array}$ & Bone & - & + & $\begin{array}{l}\text { Str } \\
\text { mitis/ } \\
\text { gordonii/ } \\
\text { oralis/peroris }\end{array}$ & 100 & 418 & Yes (4 days) & Not done & Spondylitis \\
\hline 6 & Spondylitis & Puncture & Pus & - & + & $\begin{array}{l}\text { Pseudomonas } \\
\text { sp }\end{array}$ & 97.4 & 268 & Yes (2 days) & $\begin{array}{l}\text { Str mitis (-3 } \\
\text { days) }\end{array}$ & $\begin{array}{l}\text { Spondylitis and } \\
\text { infective } \\
\text { endocarditis }\end{array}$ \\
\hline 7 & Spondylitis & $\begin{array}{l}\text { Stereotactic } \\
\text { biopsy }\end{array}$ & c Bone & Staph aureus & - & & & & No & Staph aureus & Spondylitis \\
\hline 8 & $\begin{array}{l}\text { Postoperative } \\
\text { epidural } \\
\text { abscess }\end{array}$ & $\begin{array}{l}\text { Open } \\
\text { biopsy }\end{array}$ & Pus & $\begin{array}{l}\text { Pseudomonas } \\
\text { aeruginosa }\end{array}$ & - & & & & No & $\begin{array}{l}\text { Pseudomonas } \\
\text { aeruginosa }\end{array}$ & $\begin{array}{l}\text { Postoperative } \\
\text { spondylodiscitis } \\
\text { and epidural } \\
\text { abscess }\end{array}$ \\
\hline 9 & $\begin{array}{l}\text { Vertebral } \\
\text { tumour }\end{array}$ & $\begin{array}{l}\text { Open } \\
\text { biopsy }\end{array}$ & Bone & - & - & & & & Yes $^{f}$ (4 days) & - & Spondylitis \\
\hline 10 & $\begin{array}{l}\text { Spondylitis and } \\
\text { epidural } \\
\text { abscess }\end{array}$ & $\begin{array}{l}\text { Open } \\
\text { biopsy }\end{array}$ & Bone & - & - & & & & No & - & Spondylitis \\
\hline 11 & $\begin{array}{l}\text { Epidural } \\
\text { abscess }\end{array}$ & $\begin{array}{l}\text { Open } \\
\text { biopsy }\end{array}$ & Bone & - & - & & & & $\begin{array}{l}\text { Yes }^{g}(10 \\
\text { days) }\end{array}$ & Not done & Spondylitis \\
\hline 12 & $\begin{array}{l}\text { Postoperative } \\
\text { spondylodiscitis } \\
\text { and epidural } \\
\text { abscess }\end{array}$ & $\begin{array}{l}\text { Open } \\
\text { biopsy }\end{array}$ & Disc & - & - & & & & No & - & $\begin{array}{l}\text { Postoperative } \\
\text { spondylodiscitis }\end{array}$ \\
\hline 13 & Spondylitis & $\begin{array}{l}\text { Open } \\
\text { biopsy }\end{array}$ & Bone & - & - & & & & Yes $^{h}$ & - & $\begin{array}{l}\text { Aseptic } \\
\text { spondylitis' }\end{array}$ \\
\hline 14 & Spondylitis & $\begin{array}{l}\text { Open } \\
\text { biopsy }\end{array}$ & Bone & - & - & & & & No & Not done & $\begin{array}{l}\text { Aseptic } \\
\text { spondylitis }\end{array}$ \\
\hline 15 & Spondylitis & $\begin{array}{l}\text { Open } \\
\text { biopsy }\end{array}$ & Bone & - & - & & & & No & - & $\begin{array}{l}\text { Aseptic } \\
\text { spondylitis }\end{array}$ \\
\hline 16 & Spondylitis & $\begin{array}{l}\text { Open } \\
\text { biopsy }\end{array}$ & Bone & - & - & & & & $\begin{array}{l}\text { Yes (one } \\
\text { dose) }\end{array}$ & - & Lymphoma \\
\hline 17 & Spondylitis & $\begin{array}{l}\text { Open } \\
\text { biopsy }\end{array}$ & Bone & - & - & & & & Yes (8 days) & - & Lymphoma \\
\hline 18 & $\begin{array}{l}\text { Vertebral } \\
\text { tumour or } \\
\text { infection }\end{array}$ & $\begin{array}{l}\text { Open } \\
\text { biopsy }\end{array}$ & Bone & - & + & Failure $^{i}$ & & & $\begin{array}{l}\text { Yes (one } \\
\text { dose) }\end{array}$ & Not done & Lymphoma \\
\hline 19 & $\begin{array}{l}\text { Vertebral } \\
\text { tumour or } \\
\text { infection }\end{array}$ & $\begin{array}{l}\text { Open } \\
\text { biopsy }\end{array}$ & $\begin{array}{l}\text { Epidural } \\
\text { tumour }\end{array}$ & - & - & & & & $\begin{array}{l}\text { Yes (one } \\
\text { dose) }\end{array}$ & Not done & Lymphoma \\
\hline 20 & $\begin{array}{l}\text { Vertebral } \\
\text { tumour or } \\
\text { infection }\end{array}$ & $\begin{array}{l}\text { Open } \\
\text { biopsy }\end{array}$ & $\begin{array}{l}\text { Epidural } \\
\text { tumour }\end{array}$ & - & - & & & & $\begin{array}{l}\text { Yes (one } \\
\text { dose) }\end{array}$ & Not done & $\begin{array}{l}\text { Plasma cell } \\
\text { granuloma }\end{array}$ \\
\hline
\end{tabular}

'The per cent homology and the length of the overlapping sequence for the best match.

${ }^{b}$ An effective antimicrobial treatment against the recognised microbe in the specimen; duration of preoperative antibiotic treatment is given in parentheses.

'The number of days a positive blood culture result was obtained before the specimen for the PCR assay and culture was taken are given in parentheses.

Unless otherwise indicated, blood culture was taken on the same day as the PCR.

The sample was interpreted to contain several species if the electropherogram showed strong signals but multiple overlapping peaks in some locations.

eNegative result.

The patient received ofloxacin.

The patient received ceftriaxone and metronidazole.

hThe patient received trimethoprim prophylaxis for urinary tract infection.

iAseptic spondylitis was diagnosed as one component of an autoimmune disorder of unknown origin, as described in ref 29

Sequencing failure was assumed if the sequencing signals reported by the instrument were weak.

nt, nucleotides; PCR, polymerase chain reaction.

the pre-PCR facilities from the post-PCR areas. Gamma irradiation and ultraviolet light irradiation were used to destroy possible traces of environmental bacterial DNA in the reagents. ${ }^{2122}$

\section{DNA sequencing}

The sequencing reactions were done as described earlier, either manually ${ }^{18}$ or semiautomatedly, ${ }^{10}$ by using a 373 A
Stretch DNA sequencer or an ABI Prism 310 genetic analyser (Applied Biosystems, Foster City, California, USA).

\section{Sequence analysis and databases}

The 16S rDNA study sequences were compared with those in a database made up of sequences obtained from GenBank, ${ }^{23}$ $\mathrm{EMBL}^{24}$ and the ribosomal database project ${ }^{25}$ by using an in-house algorithm. ${ }^{10}$ For comparison of the $23 \mathrm{~S}$ rDNA sequences, the FastA program was used. ${ }^{26}$ The interpretation 
of the sequencing results was based on the guidelines given by Stackebrandt and Goebel. ${ }^{27}$

\section{Conventional microbiological methods}

Samples referred for PCR analysis were at the same time also sent to the clinical microbiology laboratory of the hospital for bacterial cultures and Gram staining. For aerobic culture, the specimens were inoculated on blood agar and chocolate agar plates and incubated for a minimum of two days at $35^{\circ} \mathrm{C}$ in $\mathrm{CO}_{2}$ atmosphere. For anaerobic culture, the specimens were inoculated on fastidious anaerobe agar (LabM, Bury, Lancashire, UK), kanamycin-vancomycin agar, and bacteroides-bileesculin agar plates and incubated for a minimum of four days at $35^{\circ} \mathrm{C}$ in an MK3 anaerobic cabinet (Don Whitley Scientific, West Yorkshire, UK). Before cultivation, biopsy specimens were homogenised in brain-heart infusion broth (Gibco BRL, Life Technologies, Paisley, Scotland). Plates were examined daily for bacterial growth. Identification of isolated colonies was based on routine microbiological methods, including the VITEK system (bioMerieux, Marcy l'Etoile, France) and different API test strips (bioMerieux). ${ }^{28}$ Gram staining was done on the specimen at the request of the attending clinician. Blood cultures were taken if considered clinically indicated. For blood cultures, the Bactec 9240 system (Becton Dickinson, Sparks, Maryland, USA) was used.

\section{RESULTS}

\section{Intracranial specimens}

The final clinical diagnoses in the 24 patients with intracranial lesions included brain abscess or subdural empyema in 14, malignant tumour in seven, and demyelination, non-specific gliosis, or mucocele in one. Bacterial 23S rDNA PCR was positive in nine of the 14 pus samples from patients with brain abscesses or subdural empyemas. Eight of these 14 samples were positive on bacterial culture. Results of the PCR tests, DNA sequencing, and bacterial cultures of the intracranial specimens are given in table 1 , as are the data on the quality of the specimens, the operative technique used, preoperative antimicrobial treatment, and the final clinical diagnoses. The specimens from patients $1,2,4,5,6$, and 7 were included in our previous study. ${ }^{9}$

From six patients with brain abscesses, bacteria were detected in the specimens by both the PCR approach and bacterial culture. In five of these cases, the causative bacterial species were identified by both sequencing and culture, at least to the genus level: three cases were caused by streptococci (patients 1-3); one case by Peptostreptococcus species (patient 4); and one case by Propionibacterium acnes (patient 5). In patient 6, the brain abscess was multibacterial in aetiology-sequencing indicated the presence of several bacterial species, and bacterial culture yielded Streptococcus intermedius, Peptostreptococcus species, and Bacteroides gracilis.

Three patients with intracranial infections had specimens that were positive by PCR but negative by culture: the first had a postoperative brain abscess caused by Staphylococcus aureus, based on the sequencing result (patient 7); the second had post-traumatic brain abscesses, the specimen from which yielded Mycoplasma hominis by sequencing (patient 8); in the third case (patient 9) sequencing was not successful. In the latter, the disease was classified as probably bacterial because of the clinical features. The patient made an uneventful recovery with antimicrobial treatment.

Three patients with brain lesions had PCR negative samples, which were positive on culture. In patient 10, who had undergone neurosurgery for a meningioma, Staphylococcus aureus was identified from postoperative subdural empyema only by culture. In patient 11 , who was admitted with 15 brain abscesses, bacterial culture was the only method to reveal Fusobacterium species as the causative agent of the disease. The patient was an alcoholic with dental caries and poor oral hygiene, which was considered to be the source of the infection. In patient 21 , Propionibacterium species was grown from the third PCR negative and culture positive cerebral tissue specimen; in this patient, microbiological tests were taken as the preoperative MRI finding was suggestive of either tumour or brain abscess. On the basis of the clinical presentation and the histological finding of an astrocytoma in the tissue specimen, the culture result was designated as contamination, and the patient was not given any antimicrobial treatment.

In three patients with brain abscesses the specimens were negative by both PCR and culture. In patient 12, Aspergillus species was identified as the cause of the brain abscess at necropsy. In patient 13, Gram staining of abscess material revealed Gram positive cocci, suggesting a bacterial aetiology. In patient 14 , the disease was, on clinical grounds, most probably bacterial in origin.

PCR and bacterial cultures from brain tissue specimens were negative in seven patients with non-infectious brain disease. In addition, two patients had PCR negative intracranial samples which were not referred for bacterial culture because of the high perioperative likelihood of non-infectious brain disease.

Antimicrobial treatment and bacteriological findings

The specimens from the above intracranial bacterial infections (definite or probable) were taken during antimicrobial treatment in eight patients. The mean duration of the preoperative treatment was 5.3 days (range 12 hours to 11 days). The causative bacteria were identified by both the PCR approach and culture in three cases, by PCR alone in two cases, by culture alone in one case, and by neither method in two cases.

\section{Spinal specimens}

The final clinical diagnoses of the 20 patients with spinal lesions included spondylitis or epidural abscess in 12, aseptic spondylitis in three, lymphoma in four, and plasma cell granuloma in one. Among these samples, seven were positive by PCR and three by bacterial culture. Results of the PCR tests, DNA sequencing, and bacterial cultures of the spinal specimens are given in table 2 , as are the data on the quality of the specimens and the operative technique used, preoperative antimicrobial treatment, blood cultures, and final clinical diagnoses of the respective patients. The specimens from patients 1, 2, and 8 were included in our previous study. ${ }^{9}$

For patient 1 with spondylitis and epidural abscess, a spinal pus sample obtained during laminectomy yielded Staphylococcus aureus by culture and Staphylococcus species (probably several species) by sequencing. Eight days earlier, Staphylococcus aureus had been grown from the blood cultures of this patient, further confirming that this organism was the cause of her disease.

For four patients with spondylitis or epidural abscess, causative bacteria were identified in pus samples in two cases and in vertebral bone in two cases by the PCR approach, while bacterial cultures remained negative. Staphylococcus species and Staphylococcus aureus were identified by sequencing in the samples of patients 2 and 3, respectively. These findings were in agreement with the growth of Staphylococcus aureus from the blood cultures of both patients two weeks earlier. Streptococcus intermedius was identified by sequencing in the pus specimen taken during reoperation from patient 4 with postoperative spondylodiscitis; and Streptococcus species, in the specimen from patient 5 with spondylitis.

The PCR assay was also positive in the pus aspirate from patient 6, and sequencing of the PCR product yielded Pseudomonas species. In this patient, spondylitis and spinal abscess developed as a complication of infective endocarditis. As Streptococcus mitis growing in the blood cultures of the 
patient three days before neurosurgery was the causative agent of the endocarditis, Pseudomonas species recognised by sequencing was designated as contamination.

Sequencing was not successful for the last PCR positive and culture negative bone specimen (patient 18). Because of the final diagnosis of lymphoma and the absence of any clinical symptoms of infection, the positive PCR finding was designated as contamination in this patient.

For two patients with spondylitis (patients 7 and 8), causative bacteria were identified from pus/bone specimens by culture while the PCR assays remained negative. One of these specimens yielded Staphylococcus aureus, and the other Pseudomonas aeruginosa. The same bacterial species were grown from the blood cultures taken simultaneously from the respective patients, confirming the aetiological role of these pathogens in their diseases.

The tissue samples from 11 patients were negative on both PCR and culture. The final diagnosis was spondylitis/ spondylodiscitis of probable bacterial origin in four of these patients (9-12). In three patients (13-15), the disease was classified as aseptic spondylitis, as one component of an autoimmune disorder of unknown origin. ${ }^{29}$ In the five remaining patients (16-20), spinal tumours were diagnosed by histology.

\section{Antimicrobial treatment and bacteriological findings}

The specimens from the above spinal bacterial (either definite or probable) infections were taken during antimicrobial treatment in eight patients. The mean duration of the preoperative treatment was 8.5 days (range two to 15 days). The causative bacteria were identified from pus or tissue specimens by the PCR approach alone in four cases, by both PCR and culture in one case, and by neither method in three cases.

\section{DISCUSSION}

This study was undertaken to evaluate the usefulness of the broad range bacterial PCR and sequencing in the aetiological diagnosis of infection in patients with clinically suspected intracranial or spinal infection. We are not aware of any previous reports focusing on the systematic use of the PCR and sequencing method to identify the aetiology of bacterial infection in neurosurgical patients. The results presented here are in accordance with earlier reports on patients with other infections showing that the broad range bacterial rDNA PCR approach may be the only method to yield an aetiological diagnosis in specific situations-that is, when the specimen is taken during antimicrobial treatment or when the causative agent is fastidious. ${ }^{10} 18{ }^{10}$ In fact, all our samples with which the broad range bacterial PCR approach was the only successful investigation were taken while the patient was receiving antimicrobial treatment. Moreover, Mycoplasma hominis identified in one of these specimens is considered a fastidious microbe.

Mycoplasma hominis is a rare pathogen which normally colonises the genitourinary tract. ${ }^{31}$ It is not as fastidious as other mycoplasmas, and various media have yielded this organism. ${ }^{32}$ The few previously described cases of brain abscesses caused by Mycoplasma hominis in adults were diagnosed by bacterial culture. ${ }^{33-35}$ This is the first time that the organism has been identified from a brain abscess by a culture independent method. In our patient, preoperative treatment with clindamycin, which has recognised efficacy against Mycoplasma hominis, ${ }^{36}$ might also have contributed to the culture negativity of the abscess material. Although clindamycin penetrates poorly through the blood-brain barrier in healthy individuals, ${ }^{36}$ the situation may have been different in this patient, who had a post-traumatic brain abscess following brain contusion, leading to more effective penetration through a disturbed blood-brain barrier.

One further specimen from a brain abscess revealing Staphylococcus aureus was identified by the PCR method alone.
In five additional patients with brain abscesses, the aetiological agent was identified by both the PCR approach and bacterial culture. Except for the patients described here, data on identification of the causative bacteria by $16 \mathrm{~S}$ rDNA PCR and sequencing directly from tissue or pus specimens from brain abscess have been reported in anecdotal cases only. ${ }^{16}{ }^{17}$ Also, 16S rRNA sequencing has been applied in pure cultures from brain abscesses to identify bacteria that may be difficult to classify by their phenotypic properties. Such cases include identification of Nocardia otitidiscaviarum from a brain abscess in a renal transplantation patient ${ }^{37}$ and Abiotrophia adiacens from a brain abscess which had developed in a patient after neurosurgery. ${ }^{38}$

Among our patients with bacterial spondylitis or epidural abscess, the causative agent was identified in pus or vertebral bone specimens by the PCR and sequencing method alone in four patients, two of whom also had positive blood cultures. PCR was the only method to identify the aetiological agent in the two remaining cases from whom blood cultures were not taken. It is notable that in patients with spondylitis, the PCR method could identify the microbe in the specimen even after a long course of parenteral antimicrobial treatment-among the five patients whose specimens were successfully analysed by the PCR approach, one had received parenteral antimicrobial treatment for as long as 15 days, two for at least 12 days, and one for eight days. On the other hand, five of the six specimens taken during antimicrobial treatment from spinal lesions in patients with bacterial spondylitis were negative by culture, possibly indicating good penetration of antimicrobial agents into the spine. In our patients, blood culture proved useful as a tool to reveal the aetiology of spondylitis. In all six patients with aetiologically identified spinal infection in whom blood cultures were done, the cultures yielded corresponding pathogens.

A disadvantage associated with the application of the PCR methodology in the clinical setting is the potential for false positive results owing to cross contamination of target DNA between samples, or contamination of reagents and specimens with PCR amplicons. The use of the broad range bacterial PCR approach involves an additional risk of introducing bacterial DNA from the vessels and reagents used in various phases of sample processing and amplification. Thus rigorous measures were taken throughout the study period to avoid amplicon or sample to sample contamination and to reduce the amount of "background" bacterial DNA in the reaction. ${ }^{20-22}$ Even so, false positive amplification results may occur despite the most stringent precautions. In the present study, two positive PCR assays were considered to have been the result of contamination.

\section{Conclusions}

We found the broad range bacterial rDNA PCR approach to be useful in the aetiological diagnosis of infection in patients with brain abscesses or spinal infections. The results presented here show that in neurosurgical patients the PCR approach may be the only method to provide the aetiological diagnosis when the causative agent is fastidious, or when the patient is receiving antimicrobial treatment. In patients with bacterial spondylitis, this method may be successful even after $\geqslant 12$ days of parenteral antimicrobial treatment.

\section{ACKNOWLEDGEMENTS}

We thank Mrs Tiina Haarala, Tarja Laine, Merja Mikkola, Anne Peippo, and Kirsi Sundholm for their excellent technical work.

\section{Authors' affiliations}

L Kupila, R J Marttila, Department of Neurology, Turku University Central Hospital, Turku, Finland

K Rantakokko-Jalava, Department of Medical Microbiology, Turku University 
J Jalava, Antimicrobial Research Laboratory, National Public Health Institute, Turku

S Nikkari, O Meurman, Clinical Microbiology, Turku University Central Hospital

P Kotilainen, R Peltonen, Department of Medicine, Turku University Central Hospital

E Kotilainen, Department of Surgery, Division of Neurosurgery, Turku University Central Hospital

Competing interests: none declared

\section{REFERENCES}

1 Caugant DA, Høiby EA, Frøholm LO, et al. Polymerase chain reaction for case ascertainment of meningococcal meningitis: application to the cerebrospinal fluids collected in the course of the Norwegian meningococcal serogroup B protection trial. Scand J Infect Dis 1996:28:149-53.

2 Kristiansen BE, Ask E, Jenkins A, et al. Rapid diagnosis of meningococcal meningitis by polymerase chain reaction. Lancet 1991;337:1568-9.

$3 \mathrm{Ni} \mathrm{H}$, Knight Al, Cartwright K, et al. Polymerase chain reaction for diagnosis of meningococcal meningitis. Lancet 1992;340:1432-4

4 Cherian T, Lalitha MK, Manoharan A, et al. PCR-enzyme immunoassay for detection of Streptococcus pneumoniae DNA in cerebrospinal fluid samples from patients with culture-negative meningitis. J Clin Microbiol 1998;36:3605-8.

5 Kearns AM, Freeman R, Murphy OM, et al. Rapid PCR-based detection of Streptococcus pneumoniae DNA in cerebrospinal fluid. J Clin Microbiol 1999;37:3434.

6 Jaton K, Sahli R, Bille J. Development of polymerase chain reaction assays for detection of Listeria monocytogenes in clinical cerebrospinal fluid samples. J Clin Microbiol 1992;30:1931-6.

7 Corless CE, Guiver M, Borrow R, et al. Simultaneous detection of Neisseria meningitidis, Haemophilus influenzae, and Streptococcus pneumoniae in suspected cases of meningitis and septicemia using real-time PCR. J Clin Microbiol 2001;39:1553-8.

8 Rådström P, Bäckman A, Qian N, et al. Detection of bacterial DNA in cerebrospinal fluid by an assay for simultaneous detection of Neisseria meningitidis, Haemophilus influenzae, and streptococci using a seminested PCR strategy. J Clin Microbiol 1994;32:2738-44.

9 Rantakokko-Jalava K, Nikkari S, Jalava J, et al. Direct amplification of rRNA genes in diagnosis of bacterial infections. J Clin Microbiol 2000;38:32-9

10 Kotilainen P, Jalava J, Meurman O, et al. Diagnosis of meningococcal meningitis by broad-range bacterial PCR with cerebrospinal fluid. J Clin Microbiol 1998;36:2205-9

11 Weisburg WG, Barns SM, Pelletier DA, et al. 16S ribosomal DNA amplification for phylogenetic study. J Bacteriol 1991;173:697-703.

12 Holliman RE, Johnson JD, Savva D. Diagnosis of cerebral toxoplasmosis in association with AIDS using the polymerase chain reaction. Scand J Infect Dis 1990;22:243-4.

13 van de Ven E, Melchers W, Galama J, et al. Identification of Toxoplasma gondii infections by BI gene amplification. J Clin Microbiol 1991;29:2120-4.

14 Ohnishi K, Murata M, Kojima H, et al. Brain abscess due to infection with Entamoeba histolytica. Am J Trop Med Hyg 1994;51:180-2.

15 Isenmann S, Zimmermann DR, Wichmann W, et al. Tuberculoma mimicking meningioma of the falx cerebri. PCR diagnosis of mycobacterial DNA from formalin-fixed tissue. Clin Neuropathol $1996 ; 15: 155-8$.
16 Logan JM, Orange GV, Maggs AF. Identification of the cause of a brain abscess by direct $16 \mathrm{~S}$ ribosomal DNA sequencing. J Infect 1999:38:45-7.

17 Ley BE, Linton CJ, Longhurst $\mathrm{S}$, et al. Eubacterial approach to the diagnosis of bacterial infection. Arch Dis Child 1997;77:148-9.

18 Jalava J, Kotilainen P, Nikkari S, et al. Use of the polymerase chain reaction and DNA sequencing for detection of Bartonella quintana in the aortic valve of a patient with culture-negative infective endocarditis. Clin Infect Dis 1995;21:891-6

19 Jalava J, Mäntymaa ML, Ekblad U, et al. Bacterial 16S rDNA polymerase chain reaction in the detection of intra-amniotic infection. $\mathrm{Br} J$ Obstet Gynaecol 1996;103:664-9.

20 Kwok S, Higuchi R. Avoiding false positives with PCR. Nature 1989:339:237-8

21 Nikkari, S. Use of PCR in studies on microbial involvement in arthritis. Annales Universitatis Turkuensis. Turku: University of Turku, 1994. [Dissertation.]

22 Nikkari S, Merilahti-Palo R, Saario R, et al. Yersinia-triggered reactive arthritis. Use of polymerase chain reaction and immunocytochemical staining in the detection of bacterial components from synovial specimens. Arthritis Rheum 1992;35:682-7.

23 Benson D, Lipman DJ, Ostell J. GenBank. Nucleic Acids Res 1993;21:2963-5

24 Rice CM, Fuchs R, Higgins DG, et al. The EMBL data library. Nucleic Acids Res 1993;21:2967-71.

25 Larsen N, Olsen GJ, Maidak BL, et al. The ribosomal database project. Nucleic Acids Res 1993;21:3021-3.

26 Pearson WR, Lipman DJ. Improved tools for biological sequence comparison. Proc Natl Acad Sci USA 1988;85:2444-8.

27 Stackebrandt E, Goebel BM. Taxonomic note: a place for DNA-DNA reassociation and $16 \mathrm{~S}$ rRNA sequence analysis in the present species definition in bacteriology. Int J Syst Bacteriol 1994;44:846-9.

28 Isenberg HD. Clinical microbiology procedures handbook. Washington DC: American Society for Microbiology, 1992.

29 Kahn MF, Khan MA. The SAPHO syndrome. Baillieres Clin Rheumatol 1994;8:333-62.

30 Nikkari S, Lopez FA, Lepp PW, et al. Broad-range bacterial detection and the analysis of unexplained death and critical illness. Emerg Infect Dis 2002; 8: 188-94.

31 McCormack WM. Epidemiology of Mycoplasma hominis. Sex Transm Dis 1983;10:261-2.

32 Meyer RD, Clough W. Extragenital Mycoplasma hominis infections in adults: emphasis on immunosuppression. Clin Infect Dis 1993;17:243-9.

33 Kersten RC, Haglund L, Kulwin DR, et al. Mycoplasma hominis orbital abscess. Arch Ophthalmol 1995;113:1096-7.

34 Zheng X, Olson DA, Tully JG, et al. Isolation of Mycoplasma hominis from a brain abscess. J Clin Microbiol 1997;35:992-4.

35 Payan DG, Seigal N, Madoff S. Infection of a brain abscess of Mycoplasma hominis. J Clin Microbiol 1981;14:571-3.

36 Myhre EB, Mardh PA. Treatment of extragenital infections caused by Mycoplasma hominis. Sex Transm Dis 1983;10:382-5.

37 Hartmann A, Halvorsen CE, Jenssen T, et al. Intracerebral abscess caused by Nocardia otitidiscaviarum in a renal transplant patient - cured by evacuation plus antibiotic therapy. Nephron 2000;86:79-83.

38 Biermann C, Fries $G$, Jehnichen $P$, et al Isolation of Abiotrophia adiacens from a brain abscess which developed in a patient after neurosurgery. J Clin Microbiol 1999;37:769-71. 